\title{
WEIGHT LOSS COMPARISON AFTER SLEEVE AND ROUX-EN-Y GASTRIC BYPASS: SYSTEMATIC REVIEW
}

\author{
Comparação da perda de peso após sleeve e bypass gástrico em Y-de-Roux: Revisão sistemática
}

Fernando de BARROS¹, Mayara Galisse NEGRÃO' ${ }^{1}$, Giovana Galisse NEGRÃO²

How to cite this article: Barros F, Negrão MG, Negrão GG. Weight loss comparison after sleeve and Roux-en-Y gastric bypass: systematic review . ABCD Arq Bras Cir Dig. 2019;32(4):e1474. DOI: /10.1590/0102-672020190001e1474

From the ${ }^{1}$ Departamento de Cirurgia Gera e Especializada, Faculdade de Medicina Universidade Federal Fluminense, Niterói, RJ, Brazil, ${ }^{2}$ Faculdade de Medicina Universidade de Franca, Franca, SP, Brazi ('Department of General and Specialized Surgery, Faculty of Medicine, Fluminense Federal University, Niterói, RJ, Brazil, ${ }^{2}$ Medical College, University of Franca, Franca, SP, Brazil).

HEADINGS - Weight loss. Obesity. Bariatric surgery.Gastric bypass. Sleeve.
ABSTRACT - Introduction: Bariatric surgery is currently the gold standard treatment for obesity. The two most accomplished surgeries are the Roux-en-Y gastric bypass and the sleeve gastrectomy, and controversies exist in which is better. Objective: To compare the two techniques in relation to weight loss with at least five years of follow-up. Methods: Search in Medline, PubMed, Embase, SciElo, Lilacs, Cochrane databases from 2001 (beginning of vertical gastrectomy) until 2018, using the following headings: "sleeve" or "sleeve gastrectomy" combined with "gastric bypass" or "Roux-en-Y gastric bypass", "weight loss" and "clinical trial". Criteria for inclusion of articles were patients aged between 18 and 65 years; clinical trial; comparison between the two techniques; minimum five-year follow-up; outcome with weight loss assessment. Results: The initial search identified 1940 articles, of which 185 publications were identified as clinical trials. One hundred and forty-one were excluded, 67 because they did not compare the two techniques, 57 not addressed weight loss and 17 were repeated articles. Thirty-four studies were retrieved for a more detailed analysis; 36 studies were excluded due to a follow-up of less than five years, and another compared the mini-gastric bypass. In total, seven studies were included in the systematic review, but there was no significant difference in three of them. Conclusion: The gastric bypass had a greater weight loss than the vertical gastrectomy in all the evaluated studies.

\section{Correspondence:}

Fernando de Barros

E-mail: barroscirurgia@gmail.com

Financial source: none

Conflict of interest: none

Received for publication: 21/05/2019

Accepted for publication: 17/09/2019

DESCRITORES - Perda de peso. Obesidade. Cirurgia bariátrica. Bypass. Sleeve.
RESUMO - Introdução: A cirurgia bariátrica é atualmente o tratamento padrão-ouro para o tratamento da obesidade não passível de controle clínico. As duas operações mais feitas são o bypass gástrico em Y-de-Roux e a gastrectomia vertical, e por isso tem sido foco de muita discussão. Objetivo: Comparar as duas técnicas em relação à perda de peso com pelo menos cinco anos de acompanhamento. Métodos: As buscas dos trabalhos foram realizadas nas bases de dados eletrônicas Medline, PubMed, Embase, SciElo, Lilacs, Cochrane de 2001 (início da gastrectomia vertical) até 2018, usando os seguintes descritores: "sleeve" ou "sleeve gastrectomy" combinada com "gastric bypass" ou "Roux-en-Y gastric bypass","weight loss" e "clinical trial". Critérios de inclusão foram: trabalhos com pacientes com idade entre 18 e 65 anos; ensaio clínico; comparação entre as duas técnicas; acompanhamento mínimo de cinco anos; desfecho com avaliação de perda de peso. Resultados: A busca inicial identificou 1940 artigos, destes 185 publicações foram identificadas como ensaios clínicos. Cento e quarenta e um foram excluídos devido a que 67 não compararem as duas técnicas, 57 não abordaram a perda de peso e 17 por serem artigos repetidos. Foram recuperados 44 estudos para uma análise mais detalhada, 36 deles foram excluídos devido ao seguimento menor que cinco anos e outro por comparar o minibypass gástrico. No total sete estudos foram incluídos na revisão sistemática; no entanto, não houve diferença estatisticamente significativa em três deles. Conclusão: O bypass gástrico teve perda de peso maior que a gastrectomia vertical em todos os trabalhos avaliados.

\section{INTRODUCTION}

$\mathrm{O}$ besity is defined by excessive accumulation of potentially harmful body fat and classified by the World Health Organization as patients with body mass index $(\mathrm{BMI})>30 \mathrm{~kg} / \mathrm{m}^{224}$. The predictions are even worse: In 2025 the disease will affect one billion adults ${ }^{23}$. It is related as chronic systemic inflammation ${ }^{14}$ and metabolic disorders, among which the most common type 2 diabetes mellitus, hypertension and dyslipidemia ${ }^{11,16,17}$.

Clinical treatment is not effective for long-term sustained weight loss, as $95 \%$ of patients eventually regain their initial weight within two years ${ }^{4}$. Bariatric surgery has been considered the most effective method for treating long-term obesity, in improving the quality of life ${ }^{15}$, as well as in the remission of comorbidities that follow most cases ${ }^{5,8}$.

Currently the two most commonly performed bariatric surgeries in the world are Roux-en-Y gastric bypass (BGYR) and vertical gastrectomy $(\mathrm{GV})^{2}$. Despite many controversies regarding the comparison of techniques, both are safe and effective, 
however with slightly different comorbidities remission rates $3,6,18$.

SG as a single procedure is a relatively new technique; was started in 2001 in the US and released in Brazil in 2010 by $\mathrm{CFM}^{7,9}$. It is undoubtedly the fastest growing operation in the world and has been the most performed in the USA since $2013^{2}$. However, there are many controversies mainly regarding the maintenance of long-term weight loss.

The recent introduction in Brazil - recent compared to the time of the other techniques - associated with the large increase in the number of procedures and adept surgeons, and the emergence of numerous controversies in the long-term weight loss, has led to the aim of this review.

\section{METHODS}

The Medline, PubMed, Embase, SciElo, Lilacs, Cochrane electronic databases were retrospectively consulted from 2001 (beginning of SGS) to 2018 using the following descriptors: sleeve or sleeve gastrectomy combined with gastric bypass or "Rouxen-Y gastric bypass", "weight loss" and "clinical trial". Articles identified by the initial search strategy evaluated according to titles and abstracts, obeying the following inclusion criteria: 1) population aged 18 to 65 years; 2 ) articles with clinical trials; 3) surgical treatment comparing GV with BGYR; 4) patients with BMI greater than $35 \mathrm{~kg} / \mathrm{m}^{2}$; 5) outcome with weight loss assessment. Exclusion criteria were: 1) animal studies; 2) non-surgical intervention (such as endoscopic gastroplasty) or other operations; 3 ) studies with follow-up of less than five years; 4) studies with designs other than clinical trials; 5) non-comparative studies between the two techniques. In cases where the title and abstract were not enlightening, we found necessary to read the full article. Study results were displayed by overweight loss (PEP\%), BMI and weight

RESULTS

\section{Study description}

Figure 1 shows the flowchart of the initial search results to the selection of publications that were included for analysis and discussion. Initial research with the keywords "sleeve" OR "sleeve gastrectomy" AND "gastric bypass" OR "Roux-en-Y gastric bypass" identified 1940 articles. Seven studies selected at the end, published after 2010, and included 1014 patients in total, of whom 503 underwent BGYR and $511 \mathrm{GV}$. The sample size of the trials ranged from 64 to 240 patients. The more detailed characteristics of each study shown in Table 1.

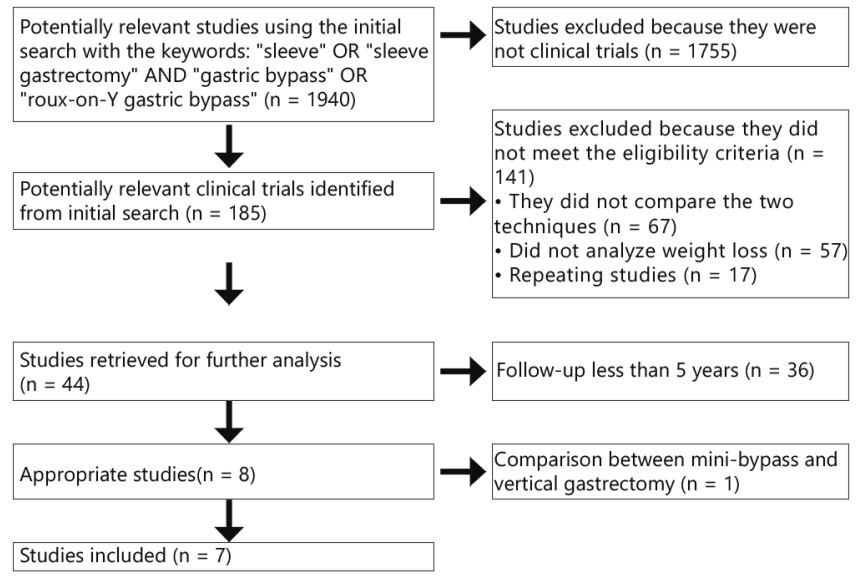

\section{FIGURE 1 - Flowchart of clinical trial selection}

Weight loss was assessed in most studies from the PEP\% which is defined by: [(preoperative starting weight - current postoperative weight) / (starting weight - ideal weight)] x 100 . Alexandrou et al. ${ }^{1}$ (2017) paper is a non-randomized clinical trial and has shown that BGYR is more efficient in long-term weight loss compared to GV $(p<0.05)$. Zhang et al. ${ }^{25}(2014)$ and Ignat et al. ${ }^{10}$ (2016) from randomized controlled trials also observed higher PEP\% in the BGYR group. Saminen et al. ${ }^{20}$ (2018) showed a greater tendency in weight loss with BGYR, however without statistically significant difference ( $p>0.05)$. The same result was identified in the non-randomized clinical trial of Leyba et al. ${ }^{13}$ (Table 2).

TABLE 1 - Characteristics of clinical trials comparing BGYR and GV

\begin{tabular}{|c|c|c|c|c|c|c|c|c|c|c|c|c|}
\hline Reference & Year & $\mathrm{N}$ & BGRY & GV & $\mathrm{RDZ}$ & Country & $\begin{array}{l}\text { Quality } \\
\text { of life } \\
\text { questionnaire }\end{array}$ & Complications & $\begin{array}{l}\text { Follow- } \\
\text { up } 5^{\circ} \\
\text { year }\end{array}$ & $\begin{array}{l}\text { DM2 } \\
\text { resolution or } \\
\text { improvement }\end{array}$ & Statistic & Efficiency \\
\hline $\begin{array}{c}\text { Alexandrou et } \\
\text { al }^{1}\end{array}$ & 2017 & 180 & 73 & 107 & NÃO & Greece (U) & & BGYR > GV & & & & BGYR > GV \\
\hline Leyba et al ${ }^{13}$ & 2014 & 117 & 75 & 42 & NÃO & $\begin{array}{l}\text { Venezuela } \\
(U)\end{array}$ & - & $\mathrm{BGYR}=\mathrm{GV}$ & $63.2 \%$ & $B G Y R=G V$ & $\begin{array}{l}\text { Wilcoxon test } \\
\text { Fisher }\end{array}$ & $\mathrm{BGYR}=\mathrm{GV}$ \\
\hline Ignat et al 10 & 2016 & 100 & 45 & 55 & SIM & France (U) & $\begin{array}{c}\text { M-A-QoLQII } \\
\text { GIQLI }\end{array}$ & $B G Y R>G V$ & - & - & $\begin{array}{c}\text { T-student } \\
\text { HLMs } \\
\text { Bonferroni } \\
\text { Wilcoxon test } \\
\text { Fisher }\end{array}$ & BGYR > GV \\
\hline Paterli et al ${ }^{19}$ & 2017 & 217 & 110 & 107 & SIM & $\begin{array}{l}\text { Switzerland } \\
\text { (M) }\end{array}$ & BARROS & $B G Y R>G V$ & $34.5 \%$ & $\mathrm{BGYR}=\mathrm{GV}$ & $\begin{array}{c}\text { T-student } \\
\text { Bonferroni } \\
\text { Fisher's }\end{array}$ & $B G Y R=G V$ \\
\hline Salminen et al ${ }^{20}$ & 2018 & 240 & 119 & 121 & SIM & Finland (M) & $\begin{array}{c}\text { M-A-QoLQII } \\
\text { GIQLI }\end{array}$ & & $80.4 \%$ & $\mathrm{BGYR}=\mathrm{GV}$ & $\begin{array}{c}\text { Test - U } \\
\text { ANOVA } \\
\text { Kolmogorov- } \\
\text { Smirnov test }\end{array}$ & $B G Y R=G V$ \\
\hline Zhang et al 25 & 2014 & 64 & 32 & 32 & SIM & China $(U)$ & M-A-QoLQII & $\mathrm{BGYR}>\mathrm{GV}$ & $84.3 \%$ & $B G R Y>G V$ & $\begin{array}{c}\text { T-student } \\
\text { test-U } \\
\text { Fisher }\end{array}$ & $B G Y R>G V$ \\
\hline Schauer et al ${ }^{21}$ & 2017 & 96 & 49 & 47 & SIM & USA(U) & $\begin{array}{l}\text { RAND 36- } \\
\text { Item } \\
\text { Health } \\
\text { Survey }\end{array}$ & & $90 \%$ & $B G Y R>G V$ & $\begin{array}{c}\text { Fisher } \\
\text { SAS software }\end{array}$ & $\mathrm{BGYR}>\mathrm{GV}$ \\
\hline Total & & 1014 & 503 & 511 & & & & & & & & \\
\hline
\end{tabular}

BGYR=Roux-en-Y gastric bypass; GV=vertical gastrectomy; RDZ=randomized; $(\mathrm{U})$ = single center; $M=$ multicenter; Moorehead-Ardelt Quality of Life Questionnaire II (M-A-QoLQII) and Gastrointestinal Quality of Life Index (GIQLI) 
TABLE 2 - Overweight loss\% according to each clinical trial

\begin{tabular}{|c|c|c|c|c|c|}
\hline & Year & BGYR & GV & p value & RDZ \\
\hline Alexandrou et al. & 2017 & 78.4 & 55.8 & $<0.05$ & No \\
\hline Zhang et al. ${ }^{25}$ & 2014 & 76.2 & 63.2 & $<0.05$ & Yes \\
\hline Ignat et al. ${ }^{10}$ & 2016 & 74.8 & 65.1 & 0.045 & Yes \\
\hline Leyba et al. ${ }^{13}$ & 2014 & 69.8 & 67.3 & $>0.05$ & No \\
\hline
\end{tabular}

Confidence interval of all studies $=95 \%$

Salminen et al..$^{20}$ (2018), Paterli et al. ${ }^{19}$ (2017) and Schauer et al. ${ }^{21}$ (2017) are not shown in the table because they did not use the PEP\% in their trials to report the difference in weight loss between the groups. Salminen et al..$^{20}(2018)$ used the estimated average percentage of excess weight loss at five years. The average percentage was $57 \%(95 \% \mathrm{Cl}, 53-61 \%)$ after BGYR and $49 \%(95 \% \mathrm{Cl}, 45-52 \%)$ after SG. In five years, the estimate was 8.2 percentage units (95\% Cl, 3.2-1.2\%) higher in the GBYR group than in the GV. However, the predefined clinical equivalence margins were -9 to +9 and based on these limits, the groups are not equivalent because the entire confidence interval is not within the margins. BGYR resulted in statistically greater weight loss than GV, but the difference was not significant. Peterli et al. ${ }^{19}$ (2017) assessed weight loss as excess percentage loss of $\mathrm{BMI}$ [initial BMI - current BMI] / (initial BMI - 25) x100]. In this study the excess loss of BMI for BGYR was $68.3 \%$ and for GV $61.1 \%$, but without statistically significant difference $(p=0.22)$. Schauer et al. ${ }^{21}$ (2017) in the STAMPEDE study compared weight loss from absolute weight. The initial mean weight and standard deviation of those submitted to BGYR was $106.8 \pm 14.9$ and after five years decreased to $83.4 \pm 15.3$ (difference of -2.2 in absolute weight, with deviation of \pm 9.6 ), whereas in GV the initial mean weight and the standard deviation were $100.4 \pm 16.8$ and the weight after five years decreased to $81.9 \pm 15.0$ (difference of -18.6 in the absolute weight and \pm 7.5 deviation) with $p=0.01$.

\section{DISCUSSION}

Obesity is a chronic, serious, progressive disease that has no cure. Because of this, the increase in incidence in recent years has become a major public health challenge. Obesity patients undergoing surgical treatment have been treated more effectively and sustainably in the long term. However, when it comes to surgical treatment, there is a wide and variable range of possibilities around the world ${ }^{2,12}$. GV since its inception has been growing exponentially and together with BGYR make up the two most commonly performed techniques today, all around the world. However, despite the growth of GV many criticisms and controversies have been brought into discussion, especially regarding the maintenance of long-term weight loss after GV.

This systematic review sought clinical trials published in the world literature that compared techniques in relation to PEP\% with follow-up for more than five years. In general, all seven selected studies show a trend of higher PEP\% in patients undergoing BGYR, although three of these studies did not show statistically significant $p^{13,19,20}$.

Leyba et al. ${ }^{13}$ (2014) performed the clinical trial with procedures performed by the same team, and the patients distributed according to their desire to perform BGYR or GV and after five years neither procedure was superior to the other in weight loss. However, they assume that there may have been selection bias in the distribution method, which eventually resulted in unequal size of the sample groups, BGYR with 75 and GV 42 patients.

The multicenter randomized large sample studies of Paterli et al. ${ }^{19}$ (2018) and Salminen et al. ${ }^{20}$ (2018) converge on results very similar to the study by Leyba et al. ${ }^{13}$ (2014). The results show equivalence between the two groups regarding the increase of quality of life, the number of reoperations or interventions and the decrease of the mean BMI value. Salminen et al. ${ }^{20}$ (2018), however, emphasize that the difference was not clinically significant due to predefined equivalence margins.

On the other hand, Alexandrou et al. ${ }^{1}$ (2017) after 180 consecutive procedures (73 BGYR and $107 \mathrm{GV}$ ), observed that patients with BMI between 35 and 55 had similar PEP\% in both techniques in the first 12 months. However PEP\% after BGYR was significantly higher than GV over the next four years. Thus, the study points out that the safety profiles of operations are similar, but BGYR achieved considerably higher PEP\% when compared to long-term GV.

Ignat et al. ${ }^{10}$ (2016), Zhang et al. ${ }^{25}(2014)$, Schauer et al. ${ }^{21}$ (2017) are single center randomized controlled trials that demonstrated well-established results. In these studies, BGYR and GV are equally safe and effective in improving quality of life and resolving comorbidities. However, when analyzing the PEP\%, the BGYR showed a statistically significant greater loss in five years.

The limitation of this review is that there is heterogeneity of the studies regarding the size of the samples, being different in operative techniques, surgeons, countries, centers, and in the way of measuring the variables. It is noted that three of these clinical trials failed to demonstrate statistically significant difference.

\section{CONCLUSION}

There is a tendency for greater excess weight loss after five years of follow-up with RouX-en-Y gastric bypass in relation to vertical gastrectomy.

ORCID

Fernando de Barros: 0000-0002-0777-4530

Mayara Galisse Negrão: 0000-0002-3870-6442

Giovana Galisse Negrão: 0000-0003-4744-0647

\section{REFERENCES}

1. AlexandrouA, Davakis S,OrfanosS. Laparoscopicroux-en-ygastricbypass versus laparoscopic sleeve gastrectomy: a single center experience. Ifso, londres, p416, 2017.

2. AngrisaniL, Santonicola A, Lovino P, et al. IFSO Worldwide Survey 2016 primary, endoluminal, and revisional procedures. Obes Surg 2018 Dec:28(12):3783-3794. doi: 10.1007/s11695-018-3450-2

3. Buchwald $H$, Avidor $Y$, Braunwald $E$, Jensen MD, Pories W, Fahrbach $K$, et al. Bariatric surgery: a systematic review and meta-analysis. JAMA 2004:292(14):1724-37.

4. Carvalho TS, Vasconcelos FC, Carvalho MDBM. Análise do histórico de métodos de emagrecimento dos pacientes submetidos à cirurgia bariátrica em um hospital público de belém-pa. Rev Bras Obes Nutr Emagrec. 2016 jan-fev; 10(55):4-11

5. Cazzo E, Gestic MA, Utrini MP, Chaim FD, Geloneze B, Pareja JC, Chaim EA, Magro DO. GLP-2: a poorly understood mediator enrolled in various bariatric/metabolic surgery-related pathophysiologic mechanisms. Arq Bras Cir Dig. 2016 Nov-Dec;29(4):272-275

6. Coelho D, Godoy EP, Marreiros I, Luz VF, Oliveira AMG, Campos JM, Caldas-Neto SS, Freitas MPC. Diabetes remission rate in different bmi grades following Roux-en-Y gastric bypass. ABCD Arq Bras Cir Dig. 2018;31(1):e1343.

7. Felberbauer FX, Langer F, Shakeri-manesch S, Schmaldienst E, Kees M, Kriwanek Setal. Laparoscopic sleeve gastrectomy as an isolated bariatric procedure: intermediate-term results from a large series in three austrian centers obes surg., 18 (7) (2008), pp. 814-818

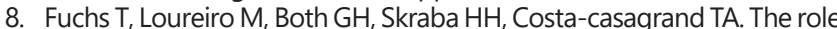
of the sleeve gastrectomy and the management of type 2 diabetes. ABCD Arq Bras Cir Dig Review Article 2017;30(4):283-286

9. Hess DS et al. Hessbiliopancreatic diversion with a duodenal switch obes surg., 8 (3) (1998), pp. 267-282

10. Ignat $M$, Vix M, Imad I. Etal. Randomized trial of roux-en-y gastric bypass versus sleeve gastrectomy in achieving excess weight loss. Wiley online library, strasbourg, 2016. 
11. Kalinowski P, Paluszkiewicz R, Ziarkiewicz-Wróblewska B et al. Liver function in patients with nonalcoholic fatty liver disease randomized to Roux-en-Y gastric bypass versus sleeve gastrectomy: a secondary analysis of a randomized clinical trial. 2017 Nov;266(5):738-745. doi: 10.1097/SLA.0000000000002397.

12. Kirkil, Cüneyt et al. Quality of life after laparoscopic sleeve gastrectomy using Baros system. $A B C D$, arq. bras. cir. dig., 2018, vol.31, no.3. ISSN 0102-6720

13. Leyba JL, Llopis SN, Aulestia SN. Laparoscopic roux-en-y gastric bypass versus laparoscopic sleeve gastrectomy for the treatment of morbid obesity. A prospective study with 5 years of follow-up. Obesity surgery, v.24, p. 2094-2098, 2014.

14. Lins DC, Campos JM, Paula OS, Galvão-Neto M, Pachu E, Cavalcanti N, Ferraz AAB. Proteína c reativa em diabéticos antes do by-pass gástrico como possível marcador de complicação pós-operatória. Arq Bras Cir Dig. 2015;28(Supl.1);11-14.

15. Mendes GA, Vargas GP.Quality of lifeaftervertical gastrectomyevaluated by the BAROS questionnaire. ABCD Arq Bras Cir Dig Original Article 2017;30(1):14-17

16. Migliore R, Gentile JKA, Franca FT, Kappaz GT, Bueno-deSouza PMS, Assef JC. Impact of bariatric surgery on the inflammatory state based on CPR value. ABCD Arq Bras Cir Dig. 2018;31(4):e1402.

17. Murphy R, Evennet NJ, Clarke MG et al. Sleeve gastrectomy versus Roux-en-Y ggastric bypass for type 2 diabetes and morbid obesity: double-blind randomized clinical trial protocol. BMJ Open. $2016 \mathrm{Jul}$ 4;6(7):e011416. doi: 10.1136/bmjopen-2016-011416.
18. Ngiam KY, Lee WJ, Lee YC, Cheng A. Efficacy of metabolic surgery on $\mathrm{HbA} 1 \mathrm{c}$ decrease in type 2 diabetes mellitus patients with $\mathrm{BMl}<35 \mathrm{~kg} /$ m2 - A review. Obes Surg [Internet]. 2014;24(1):148-58.

19. Paterli, r., et al. Effect of laparoscopic sleeve gastrectomy vs laparoscopic roux-en-y gastric bypass on weight loss in patients with morbid obesity the sm-boss randomized clinical trial. Jama, v.319, n. 3, p. 255-265, 2018.

20. Salminen, p., helmiö, m., ovaska, j., et al. Effect of laparoscopic sleeve gastrectomy vs laparoscopic roux-en-y gastric bypass on weight loss at 5 years among patients with morbid obesity the sleevepass randomized clinical trial. Jama, v.319, n. 3, p. 241-254, 2018.

21. Schauer, p. R., bhatt, d. L., kirwan, j. P., et al. Bariatric surgery versus intensive medical therapy for diabetes -5 -year outcomes. The new england journal of medicine v. 51, p. 376-641, 2017

22. Silver HJ, Torquati A, Jensen GL, Richards WO. Weight, dietary and physical exercises behaviors two years after gastric bypass. Obes Surg. 2006; 16:859-864.

23. Word Helth Organization. Obesity and Overweight. [Acessado em 26 março 2019] Disponível em: https://www.who.int/gho/ncd/risk_factors/ overweight

24. World Health Organization (WHO). Obesity: preventing and managing the global epidemic. Report of a WHO Consultation. WHO Technical Report Series (894). Geneva, 2000.

25. Zhang, y., zhao, h., cao, z., et al. A randomized clinical trial of laparoscopic roux-en-y gastric bypass and sleeve gastrectomy for the treatment of morbid obesity in china: a 5-year outcome. Obesity surgery, 2014. 